\title{
Energy Saving Performance of Detached House with Hydrogen Co-generation System
}

\author{
Lianping Xu, Weiju Gao \\ Faculty of Environmental Engineering, University of Kitakyushu, Kitakyushu, Japan \\ Email: jimxlp@hotmail.com
}

Received 24 June 2015; accepted 27 July 2015; published 30 July 2015

Copyright $(02015$ by authors and Scientific Research Publishing Inc.

This work is licensed under the Creative Commons Attribution International License (CC BY). http://creativecommons.org/licenses/by/4.0/

(c) (i) Open Access

\begin{abstract}
Energy consumption is increasing every year in building sector, utilization and development of alternative energy sources and technologies to support the requirements of every house. The hydrogen fuel cell is one of the latest technologies for distributed energy systems. This research is aim to grasp the energy saving performance of the hydrogen co-generation system in the detached house. First, it investigated on the demand-side energy consumption including electricity, cooling, heating and hot water. Second, it introduced a distributed energy resources (DER) system and set six cases to analyze the energy utilization. Different options for changing the heating, cooling, electricity and hot water systems were compared for this type of detached house, assuming basiccase as a reference. Changes in the fuel used, energy operation machines and also demand side and supply side were analyzed. Except past case, every case will be operated under the electricitytracking mode and heat-tracking mode. The comparisons and evaluations of the energy consumption between cases can suggest the environmental performance of the hydrogen co-generation system.
\end{abstract}

\section{Keywords}

DER System, Hydrogen Fuel Cell, Simulation, Detached House

\section{Introduction}

The world energy consumption has increased fiercely year by year that we should focus more on the energy using efficiency and energy conservation. As the fossil fuel gradually dried up, it also caused problems of the global warming. In order to control the pollution and make sustainable development, renewable energy and untapped technologies should be taken further attention. The energy generating for power grid makes a big loss. The distributed energy system, using the bottom-up energy system design strategies, together with the onsite re- 
newable energy use can meet the energy consumption of the demand side and make good use of the characteristics of the energy as well as smooth the grid fluctuate. It will cut down the need of fossil fuel and get a more environmental energy generation. In general, distributed energy system is a comprehensive energy utilization system. It includes power generation facilities and at the time, provides the need of heating or cooling with making use of waste heat from the generation system. The distributed energy system has a wider choice and has a potential to offer consumers a lower cost, higher service reliability, high power quality and energy independence. The renewable energy resources are can also be introduced to the distributed energy system, like wind, photovoltaic, geothermal, biomass and hydroelectric power.

The growing worldwide demand for less polluting forms of energy has led to a renewed interest in the use of micro combined heat and power (CHP) technologies in the residential sector [1]. The operation of micro CHP system results in simultaneous production of heat and power in a detached house as small energy conversion units. The heat may be used for space and water heating and possibly for cooling use if combined with an absorption chiller and the electricity is used within the house [2] [3]. For each building type, the energy demands for electricity and heat are dynamically determined. Using these load profiles, several CHP systems are designed for each building type [4] [5].

Primary energy and electricity consumption, associated greenhouse gas emissions and tolerable capital cost are used as indicators [6]. A whole building simulation model was used to simulate the performance of a commonly used cogeneration system with thermal storage in typical single detached houses located in Japan. A high efficiency gas boiler is included to supply heat when cogeneration unit capacity is not sufficient to meet the heating load. The effect of thermal storage capacity, interest rate and acceptable payback period on the overall performance was evaluated through a sensitivity analysis.

The maximum exploitation of local renewable energy sources is a key feature of DER systems: to this aim, Hybrid Power Systems, integrating renewable and non-renewable power sources with local energy storage may represent an effective solution, although they may require an optimum utilization of the different sub-systems, for example if including fuel cell [7]-[9]. Setting new applicable sustainable design guidelines for detached houses [10], the basic assumption is that heating and cooling has play an important role in future sustainable energy systems [11]-[16].

The DER system in the detached house as micro-cogeneration, also termed micro combined heat and power or residential cogeneration, is an emerging technology with the potential to provide energy efficiency and environmental benefits by reducing primary energy consumption and associated greenhouse gas emissions. The distributed generation nature of the technology also has the potential to reduce losses due to electrical transmission and distribution inefficiencies and to alleviate utility peak demand problems [17] [18].

This research investigated the demand-side energy consumption including electricity, cooling, heating and hot water in the detached house with co-generation system including gas-burned fuel cell and hydrogen-based fuel cell. Then introduced a distributed energy resources system and set six cases to analyze the energy utilization. Lastly, the comparisons and evaluations have been carrying out in order to understand the environmental performance of the hydrogen co-generation system.

\section{Study Objective and Its Load Performance}

From Figure 1 we will separate three parts to explain the research flow. Firstly we calculated the load of detached house, including electricity, heating \& cooling and hot water. Then we set six cases for different distributed energy system, and for each case, we calculated power generation and heat production according to energy supply and demand to analysis [19]. At last we evaluated the results about energy saving and environmental protection.

An illustrate example of the model usage is presented below. It is a two-floor residential building in Kitakyushu Japan, having a total floor area of $250 \mathrm{~m}^{2}$. A residential hydrogen CHP system is considered for adoption. The Yearly, monthly and hourly energy consumption are estimated according to the energy consumption unit and the building area. From Figure 2, we can know that the electricity load in each month stable at around 1000 $\mathrm{kW}$, do not change so much. But in the May, the value is higher than other month, reaches $1175 \mathrm{~kW}$. The maximum value of cooling and heating load is $1592 \mathrm{~kW}$ in January. In May, June and October, do not need to consume the cooling and heating load. The hot water load in January has the maximum value, which reaches 784 $\mathrm{kW}$. 


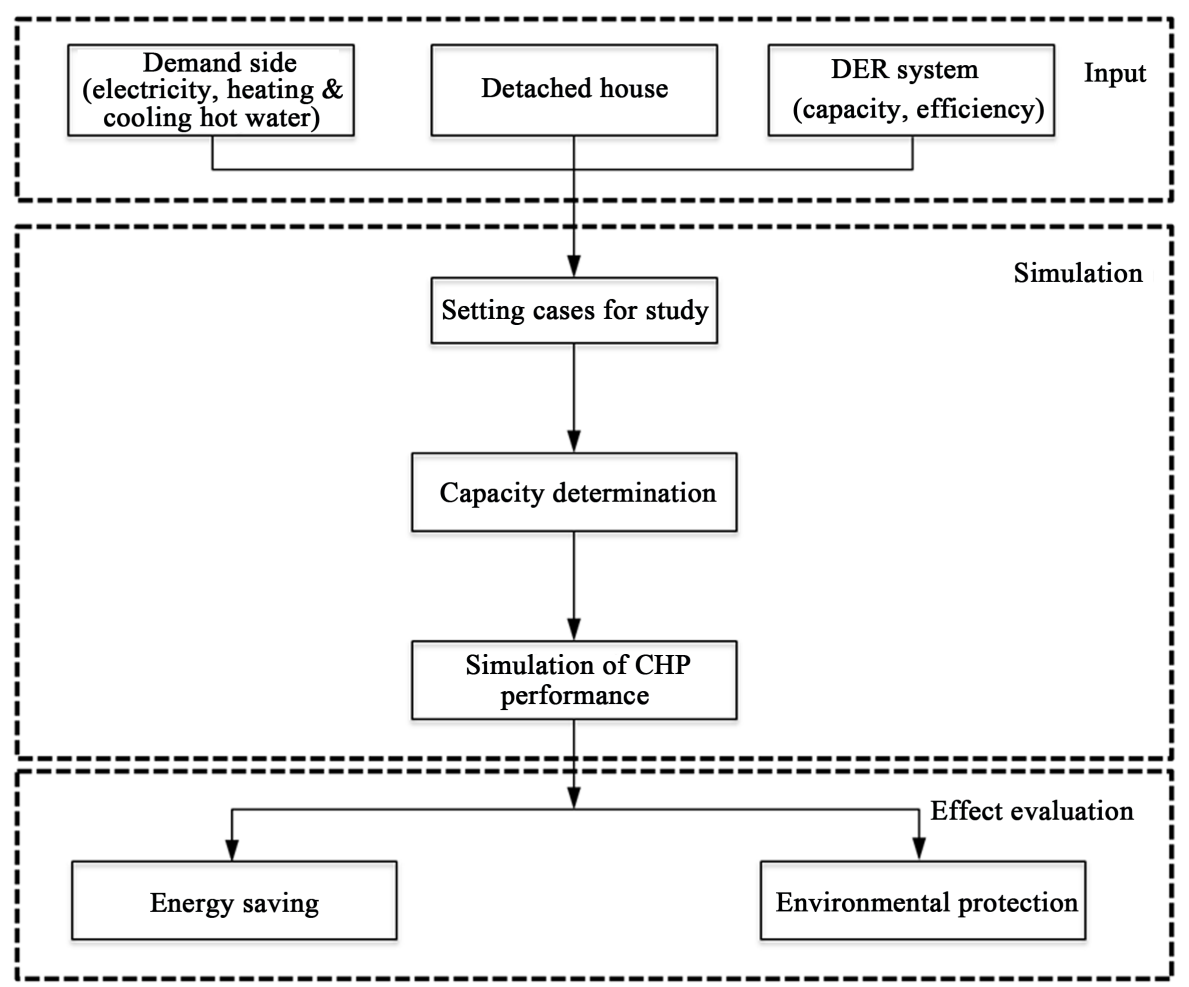

Figure 1. Research flow.

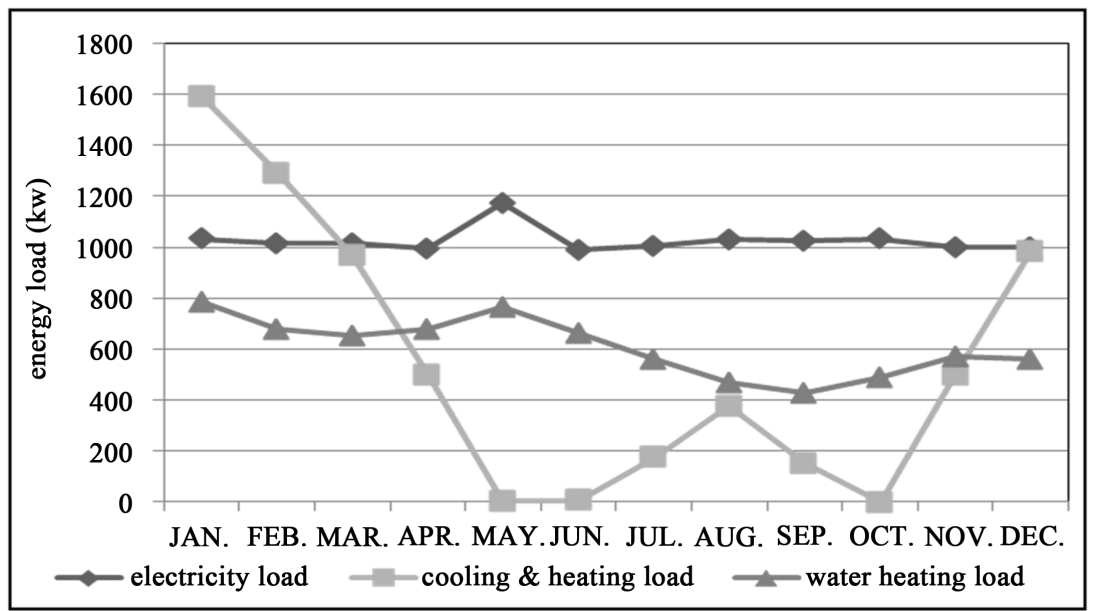

Figure 2. Energy load of detached house.

We select January, August and October as the representative months to indicate characteristics of winter period, summer period and interim period. Figure 3 represents the hourly average value of detached house energy load in winter period. The heating load in winter has two peaks during a day: one is from 7 o'clock to 9 o'clock in the morning; another is from 17 o'clock to 22 o'clock in the evening. Hot water load has a low peak in the morning and the period between 20 o'clock and 23 o'clock.

Figure 4 represents the energy consumption in summer period. For detached houses, the electricity load is higher than other energy consumption. The peak of cooling load in summer is from 19 o'clock to 21 o'clock in the evening. The hot water load reaches the maximum value at 20 o'clock.

Figure 5 represents the detached house energy consumption in interim period. There is no cooling and heating load in October and electricity load is higher than hot water load. The peak period of electricity load is be- 


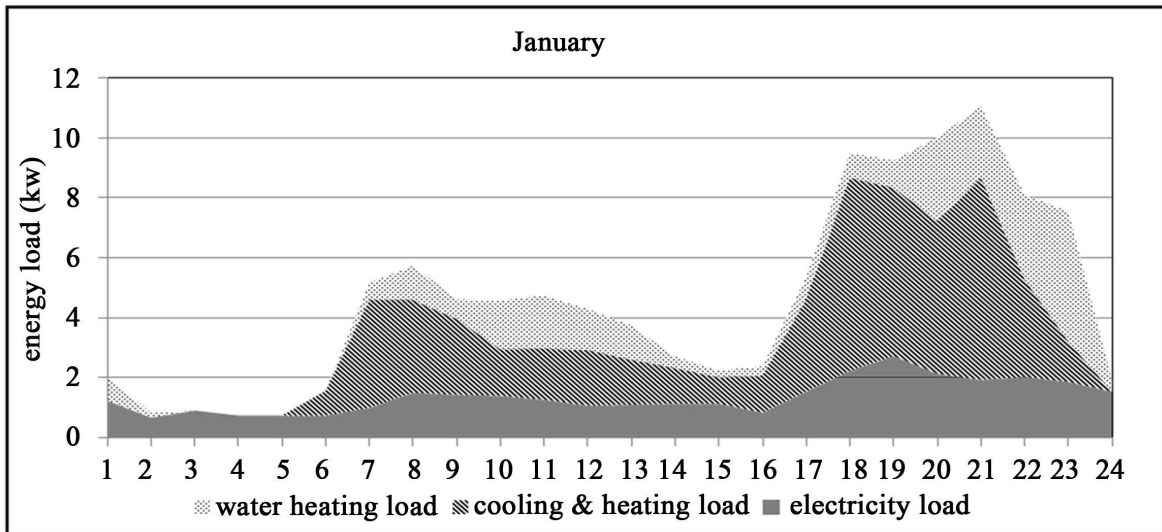

Figure 3. Energy load in January.

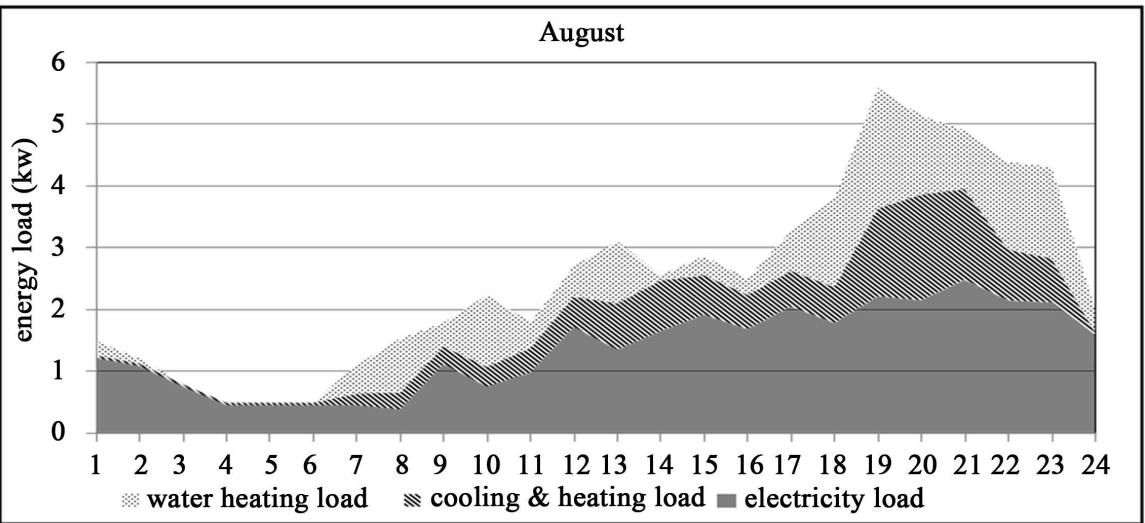

Figure 4. Energy load in August.

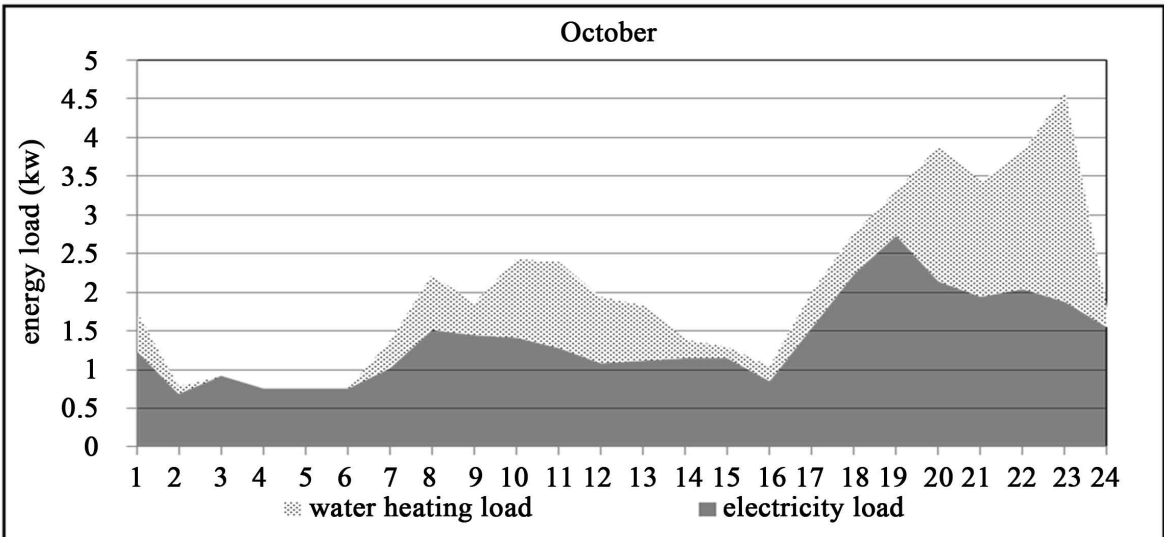

Figure 5. Energy load in October.

tween 18 o'clock and 23 o'clock. The hot water load has two peaks during a day: one is between 10 o'clock and 11 o'clock in the morning and another is between 20 o'clock and 23 o'clock in the evening.

\section{Energy SystemDecision}

\subsection{System Setting}

According to the basic survey about this detached house, this research set up 6 cases to analyze energy utiliza- 
tion conditions. Different equipment will provide electricity load, cooling load, heating load and water heating load for the detached house. Figure 6 represents the conventional energy system of detached house. The system uses grid for the electricity supply, the air conditioner for cooling and heating, and gas boiler for hot water supply.

Figure 7 represents the case 2 that use gas fuel cell co-generation system to supply energy to the detached house. The overall efficiency is much higher than the power generation efficiency from power plant. Part of the electricity load is from the fuel cell power generation, the other is from grid power generation.

From Figure 8, we use hydrogen fuel cell to replace gas fuel cell as the energy resource. This hydrogen fuel cell can be set in compact community, detached house and apartment.

Figure 9 is the system considered both hydrogen fuel cell and the PV system. The PV system can generate electricity during the daytime. But the efficiency is affected by the weather condition.

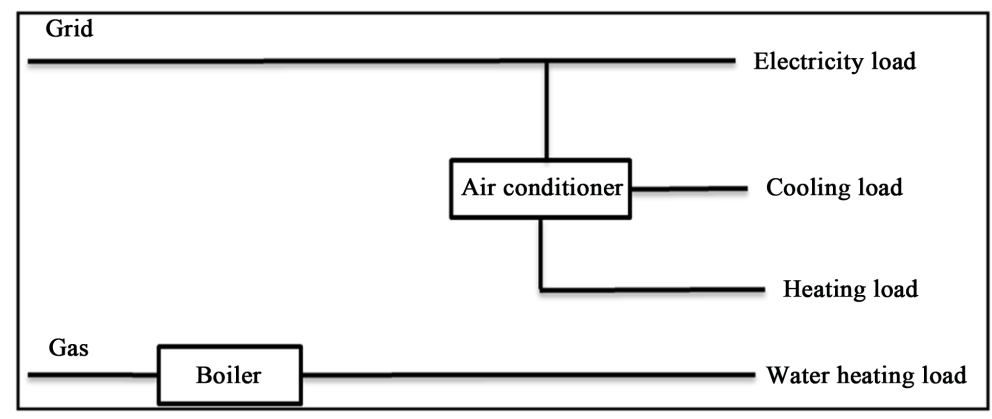

Figure 6. Case 1 (conventional case).

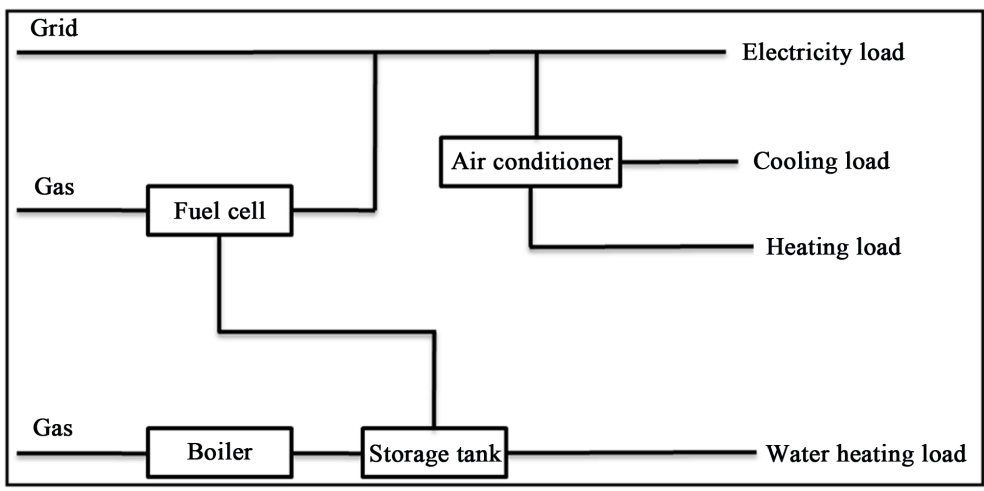

Figure 7. Case 2 (FC by gas).

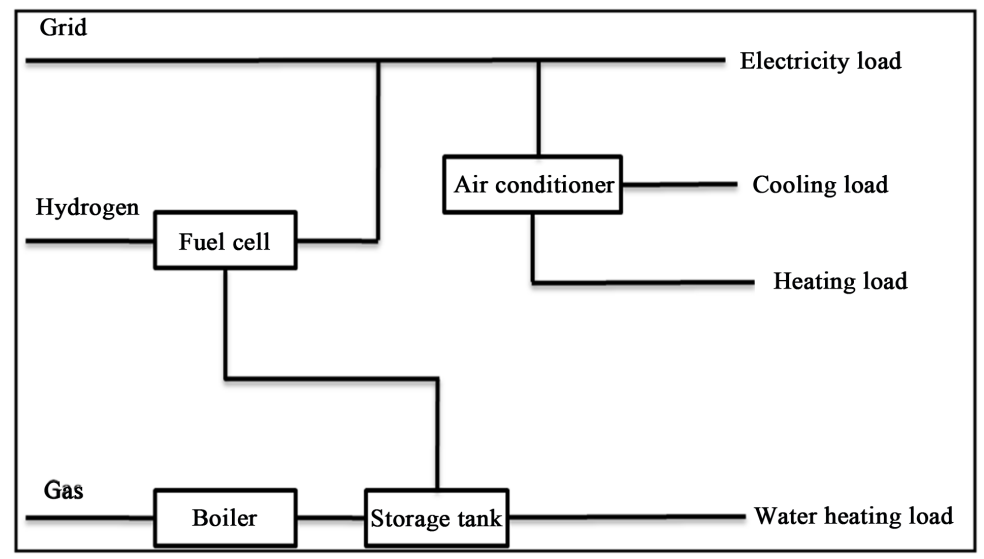

Figure 8. Case 3 (FC by hydrogen). 


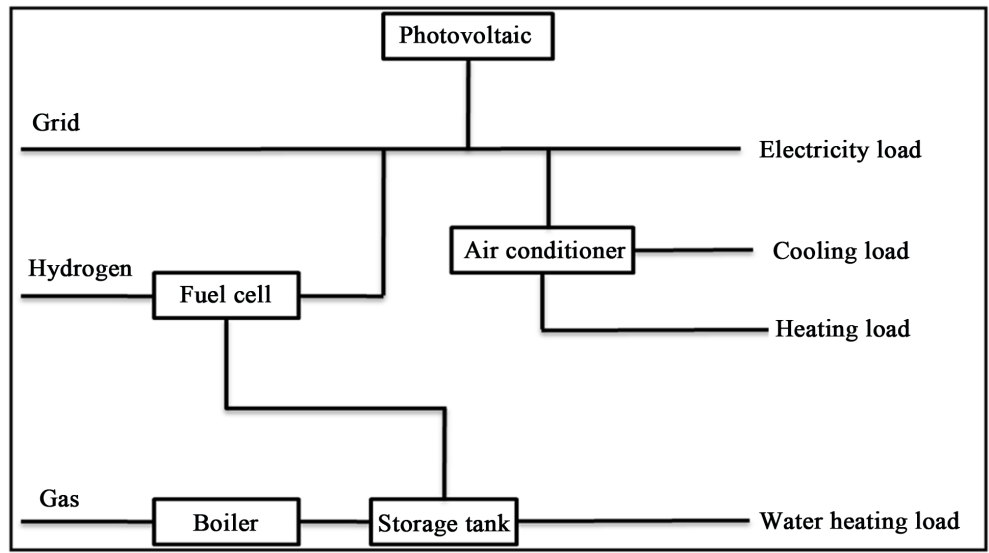

Figure 9. Case 4 (FC + PV).

In case 5 and case6 (Figure 10 and Figure 11), the research introduced storage batteries in the detached house. The charging time and discharging time are stationary in case 5 but floating in case 6 . In case 5, the battery is only charged by the grid but in case6, the battery charged by power grid, solar panel and fuel cell. So the electricity of the storage batteries will been regulated in case 6 . In heat-tracking mode, storage batteries can utilize more residual electricity to save energy.

\subsection{Operation Condition and Machine Selection}

When we finished the cases setting, we need to judge operating conditions of each case and set parameters of each equipment.

From case 2 to case 6, the systems are operated in two modes, the electricity-tracking mode and the heattracking mode. The electricity-tracking mode means the electricity produced by the distributed energy system meet the electricity demand. At the same time, the recovery heat is used for heating, cooling and hot water. In this mode, there is no left electricity. The storage batteries in this mode will be filled firstly by the residual electricity from the solar system. The fuel cell will not charge the battery. Sometimes the recovery heat cannot be fully utilized.

The heat-tracking mode means the recovery heat can meet the heat demand in the detached house. The recovery heat can fully utilized and the residual electricity will be stored in the battery. The battery will prior charged by the fuel cell and then by solar power generation and the grid.

Figure 12 represents the priority selection of electricity load. When the detached house needs electricity, the first choice is solar panel, second is power generation from fuel cell. If it is still not enough to supply electricity load, use storage batteries to regulate. At last, we will use electricity from power grid to supply electricity load. Figure 13 represents the priority selection of heat, which firstly from fuel cell and then supplement by the auxiliary boiler.

The $\mathrm{CO}_{2}$ emissions are estimated by the $\mathrm{CO}_{2}$ emissions rate of grid and city gas. The efficiency of the facilities is set as Table 1 .

Calculate the equipment use electricity or gas that how much the energy can be generated. It is the basic thing to simulate the energy operating conditions of the detached house.

\section{Simulation Results}

\subsection{Power Utilization and Heat Utilization}

The analysis in this part took the case 6 as the example. Figures 14-20 are the simulation results.

Figure 14 is the monthly electricity consumption under the electricity-tracking mode. In case 6 , the charging time and the storage batteries follow the electricity load. The residual electricity produced by PV can be stored. The hydrogen fuel cell power generations table at around $400 \mathrm{~kW}$ in each month. October has the largest solar power generation which reaches $442 \mathrm{~kW}$. January has the least solar power generation which reaches $210 \mathrm{~kW}$. 


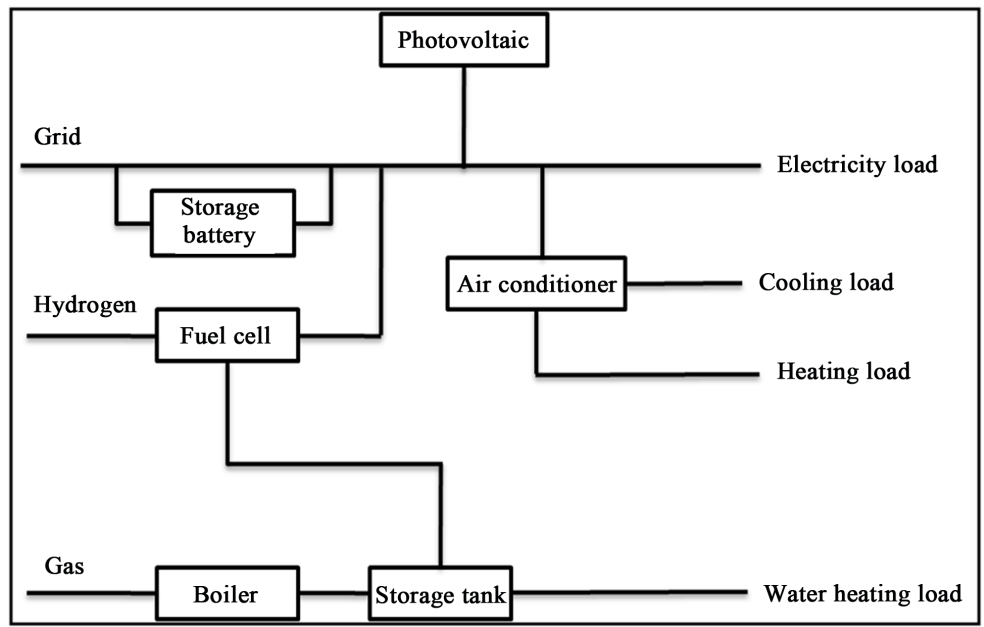

Figure 10. Case $5(\mathrm{FC}+\mathrm{PV}+\mathrm{SB})$.

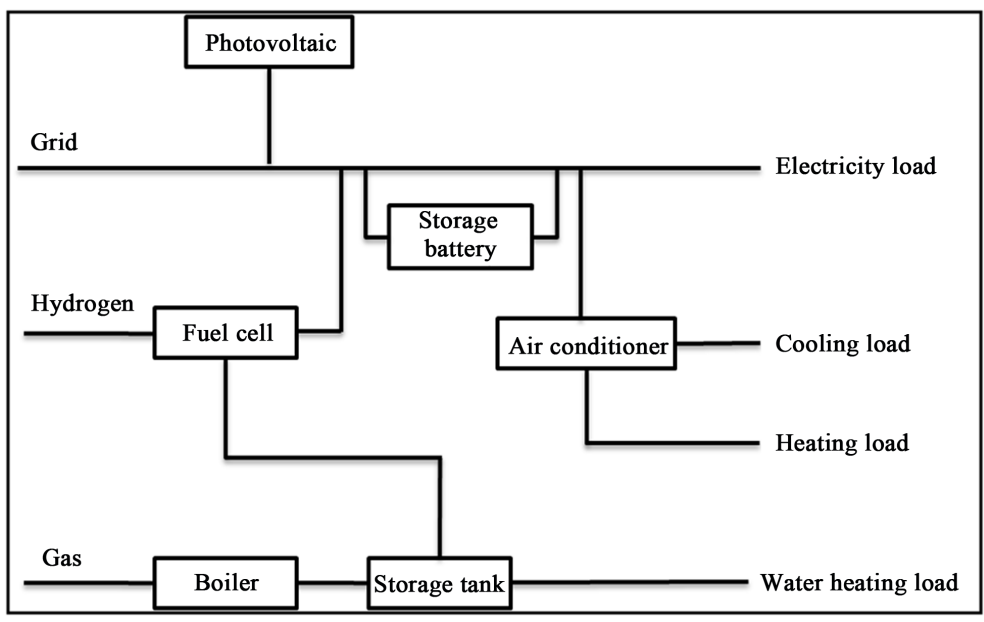

Figure 11. Case $6(\mathrm{FC}+\mathrm{PV}+\mathrm{SB})$.

Table 1. Parameter of each facility.

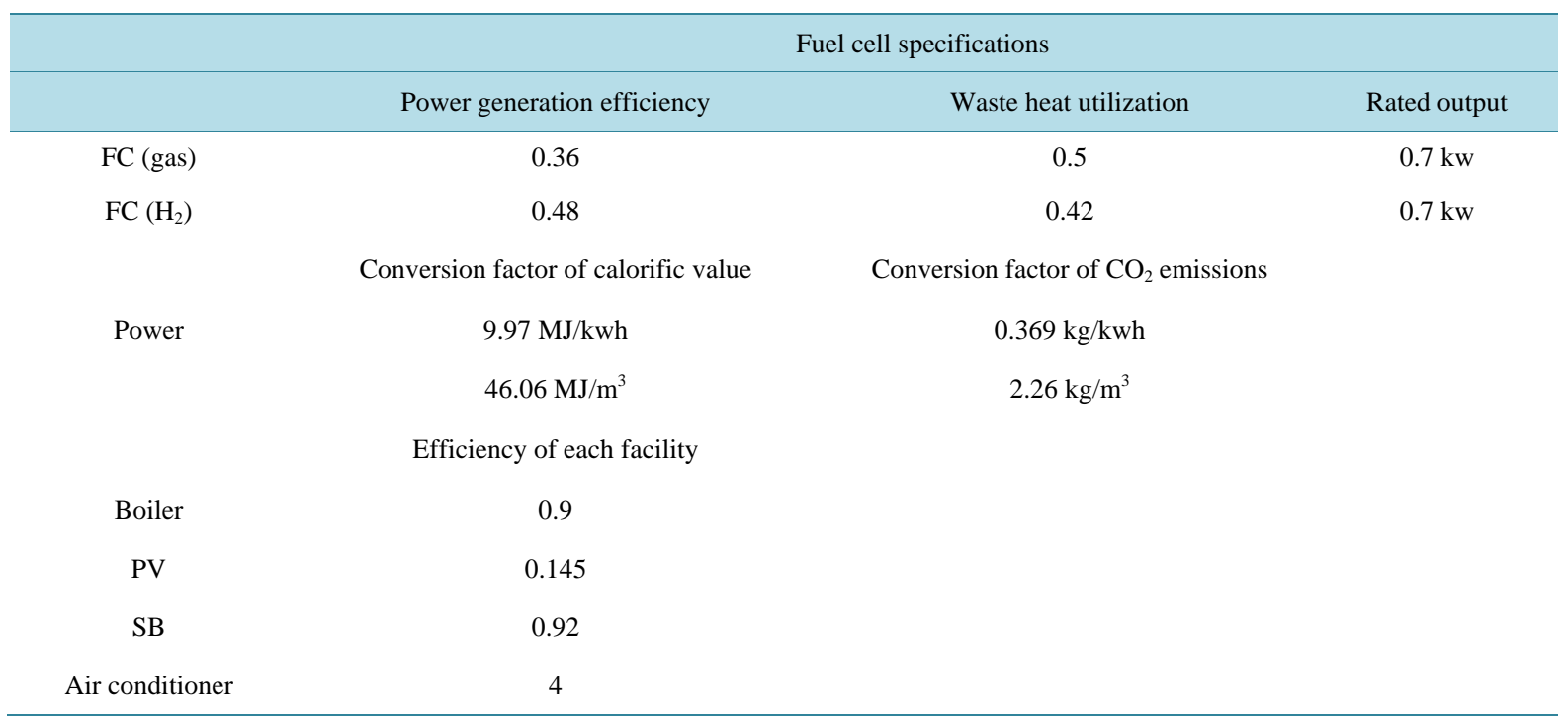




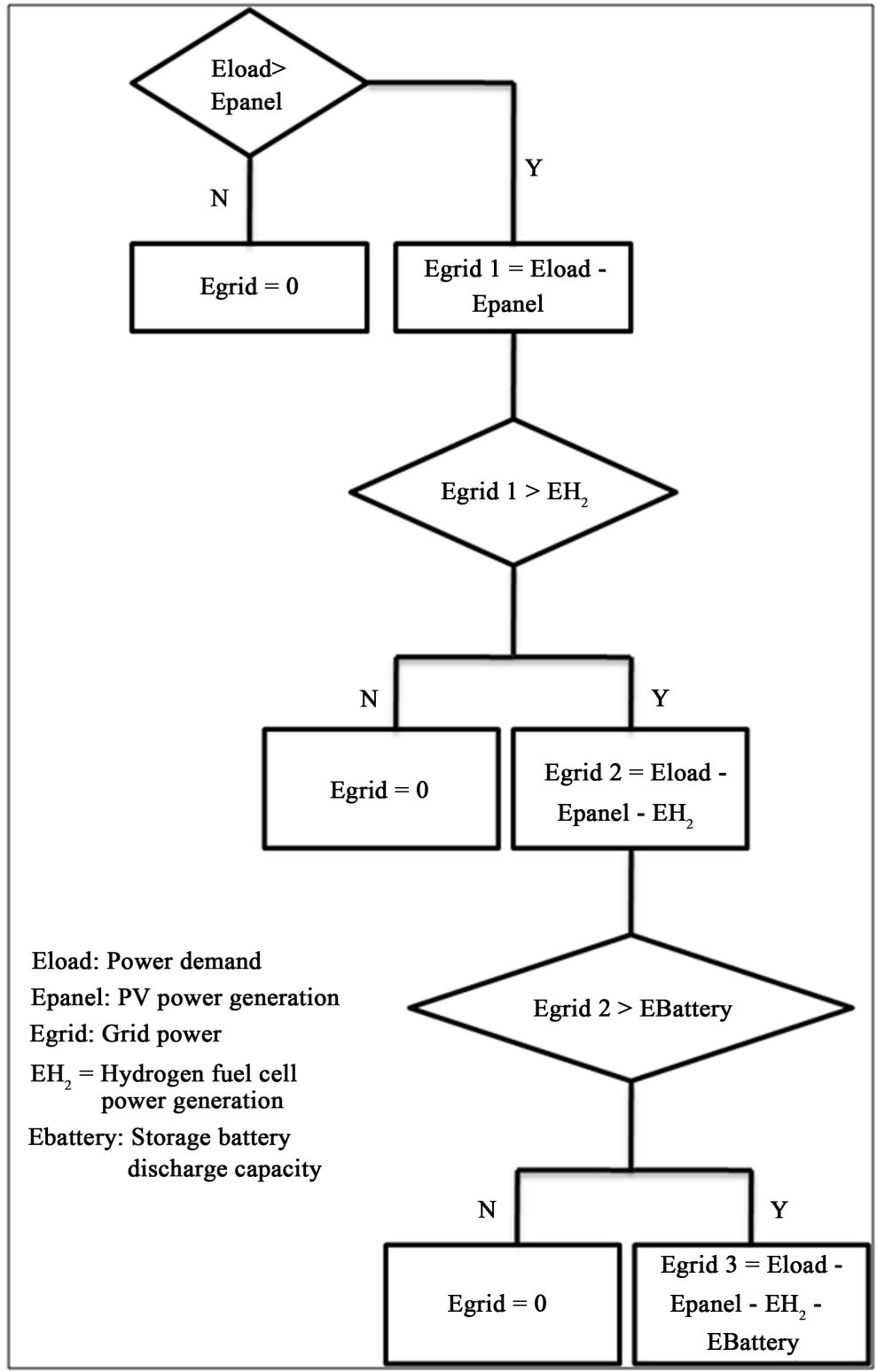

Figure 12. The condition of electricity use.

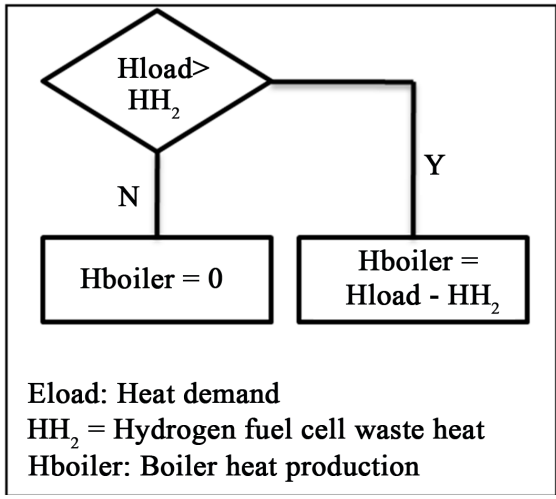

Figure 13. The condition of heat use. 


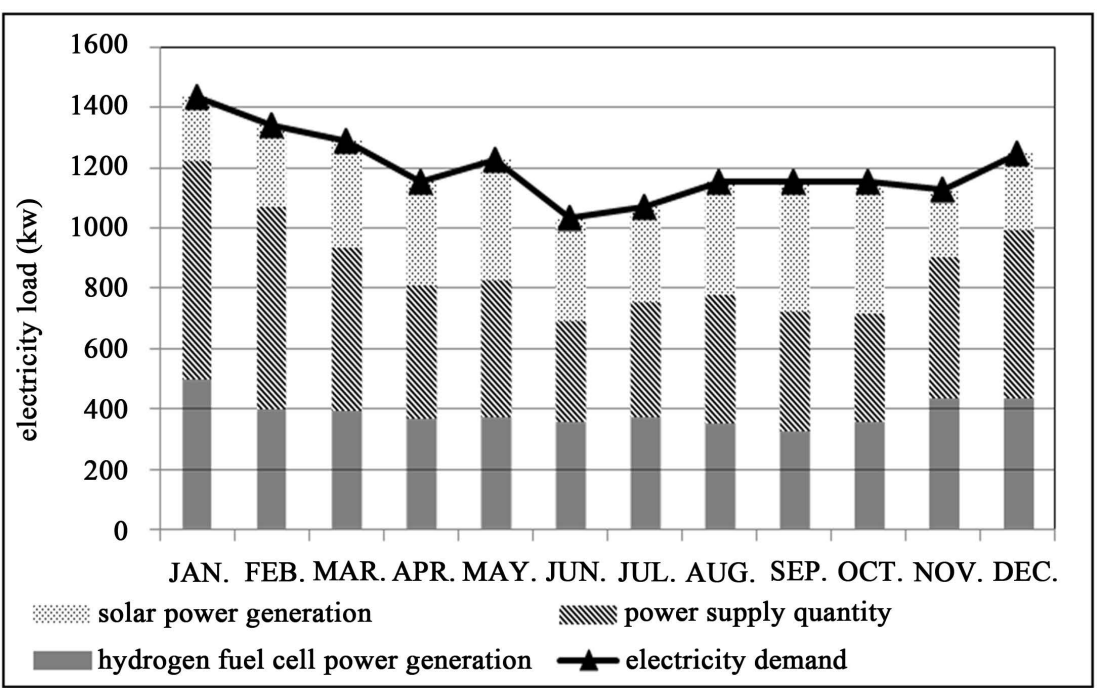

Figure 14. Electricity consumption structure (case 6 mode 1).

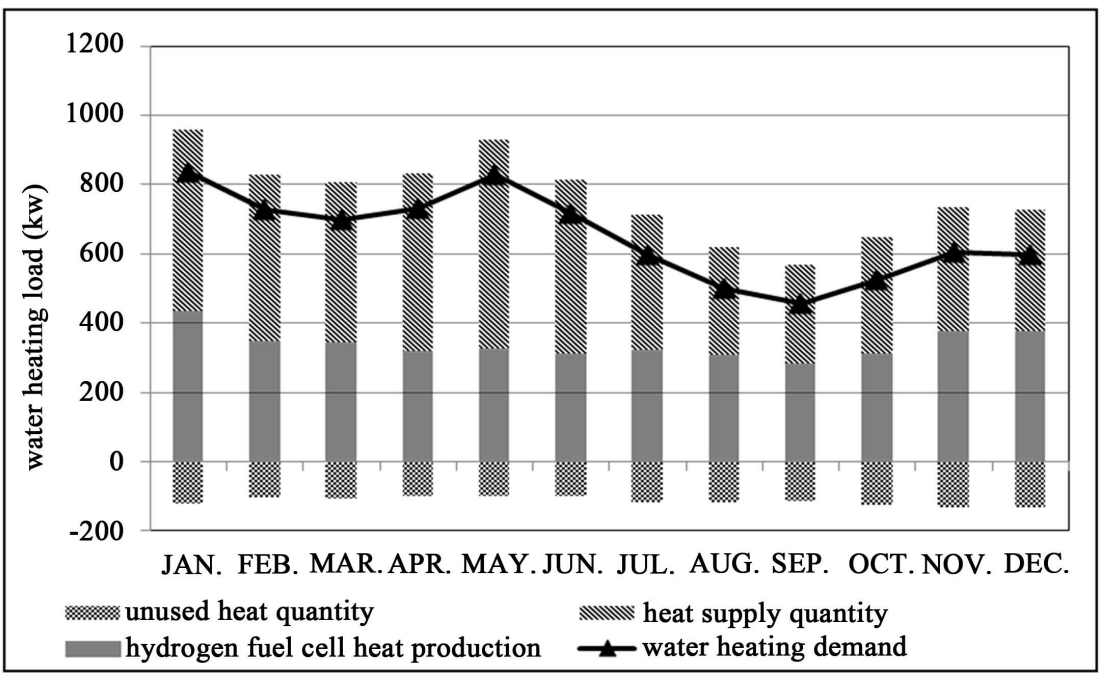

Figure 15. Heat consumption structure (case 6 mode 1).

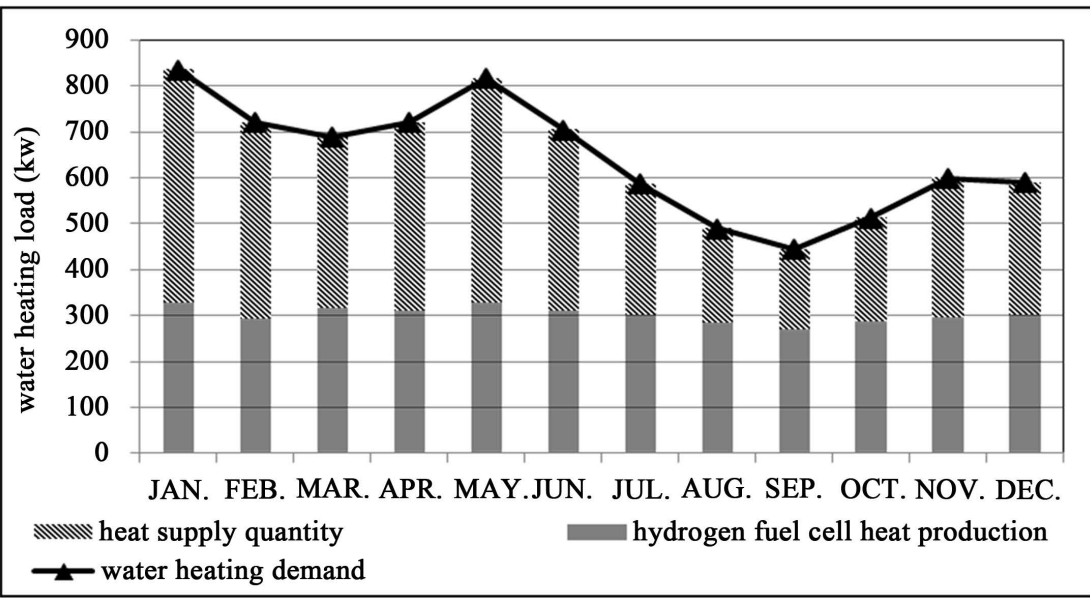

Figure 16. Heat consumption structure (case 6 mode 2). 


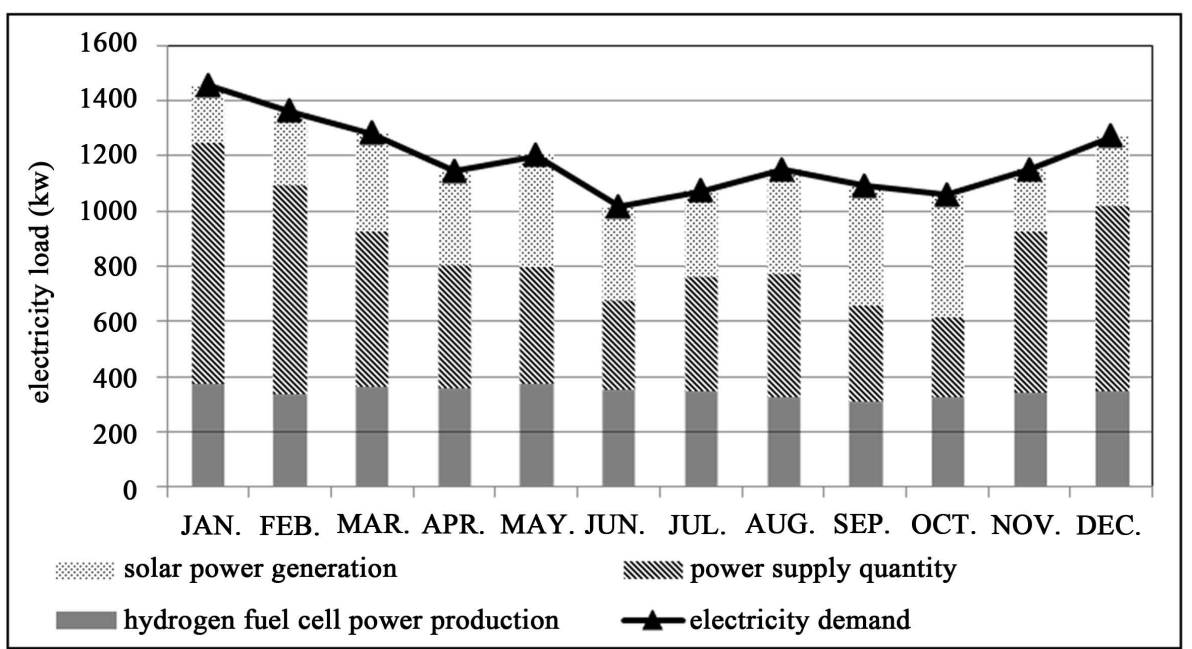

Figure 17. Electricity consumption structure (case 6 mode 2).

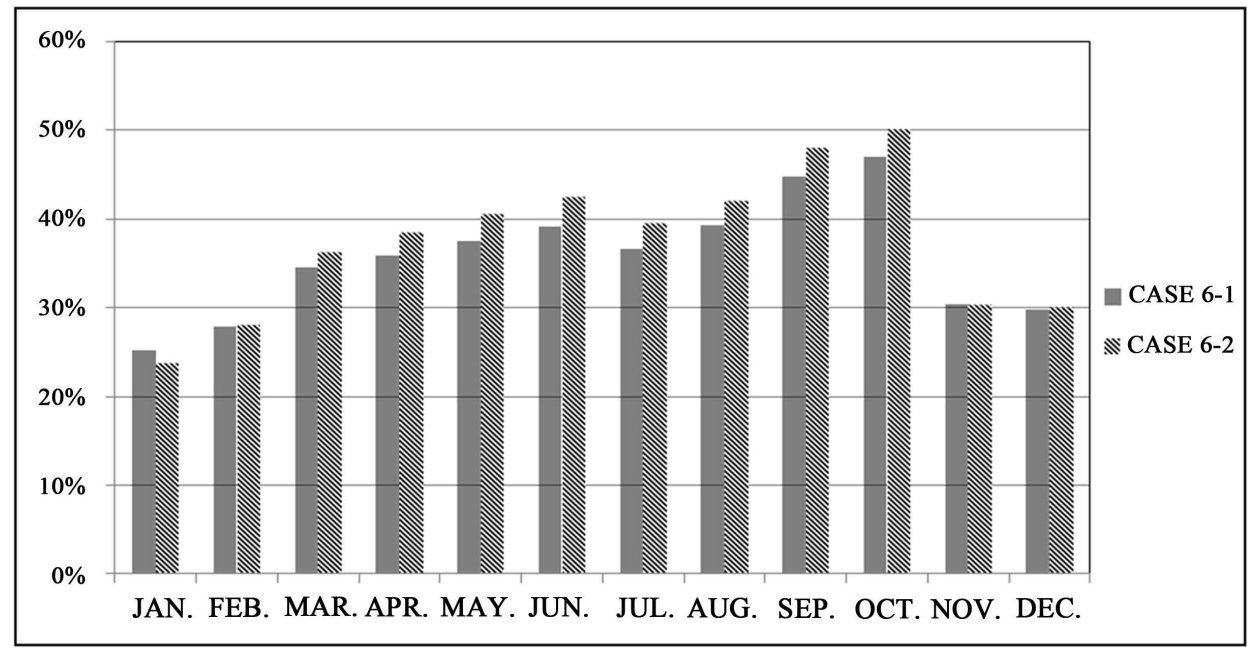

Figure 18. Energy reduction rate per month.

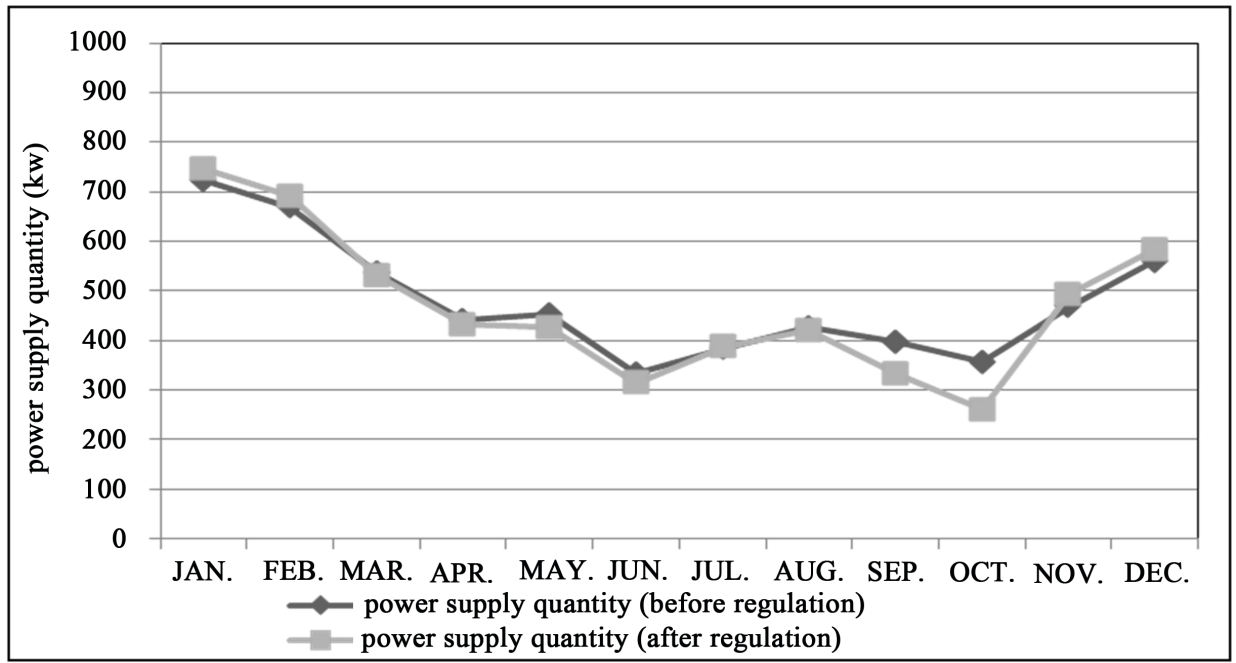

Figure 19. Regulation of storage batteries per year (mode 1). 


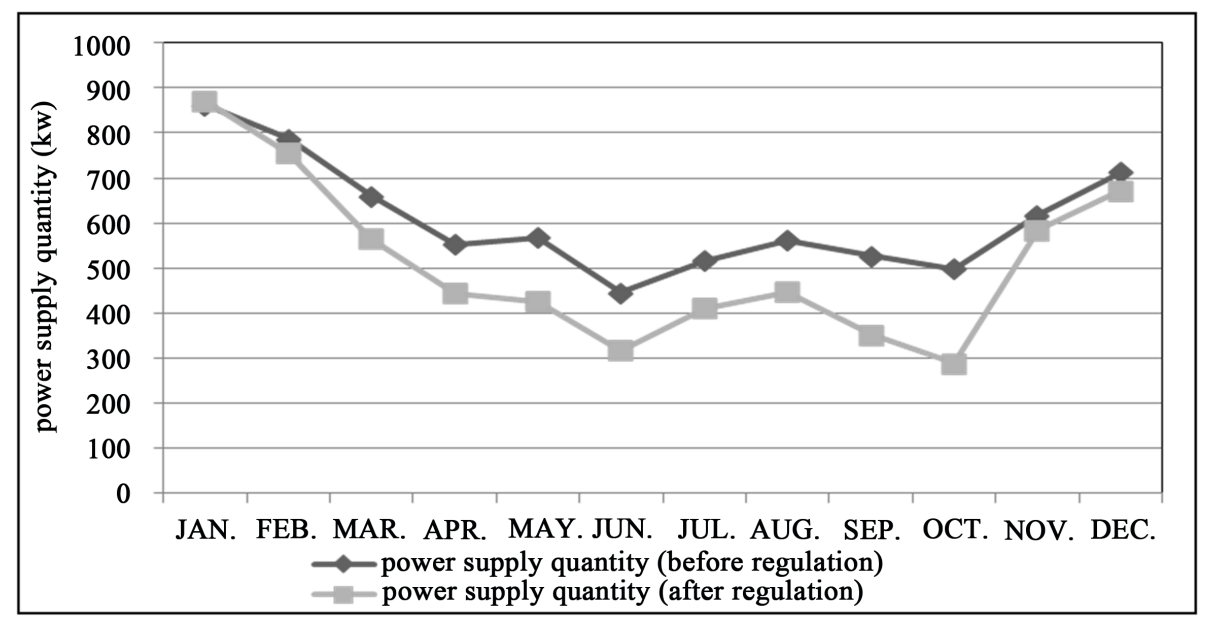

Figure 20. Regulation of storage batteries per year (mode 2).

Figure 15 is the heat consumption structure. The heat produced by fuel cell is determined by hydrogen fuel cell power generation. It is suggested that the unused heat quantity is from the fuel cell heat production. In each month unused heat quantity has around $100 \mathrm{~kW}$ losses.

Figure 16 is the heat consumption structure under the heat-tracking mode and there is no residual heat. Hydrogen fuel cell heat production is only about $300 \mathrm{~kW}$ in each month.

Figure 17 is the electricity consumption structure under heat-tracking mode. Power supply quantity in January reaches $871 \mathrm{~kW}$ which is the maximum value and in October reaches $289 \mathrm{~kW}$ which is the minimum value.

\subsection{Energy Conservation Regulation}

There is no doubt that the primary energy consumption of past case has the maximum value. When we introduced the fuel cell, solar panel and storage batteries in this system, the primary energy consumption is less than previous case. When we set up the PV system in the detached house, the energy reduction rate can reach more than $15 \%$ and also have waste. From Figure 18, we can clearly know that energy reduction of heat-tracking mode is greater than electricity-tracking mode in most of the time.

From Figure 19 and Figure 20, unused electricity from solar panel and fuel cell is greater than the energy loss of conversion efficiency under heat-tracking mode. But under electricity-tracking mode, there is no unused electricity from fuel cell. Power quantity depends on the solar generation, so the solar radiation rate of some months caused the low power supply quantity.

\section{Conclusions}

As the energy shortage has become the focus on a global scale. On the other hand, the residential building is a big part of energy consumption. So the energy conservation has become more and more important for the society.

General generating efficiency of power grid makes a big loss where it is generating in plants. Distributed energy resources system enhances the efficiency, and also is faster than before. Offer consumers the potential for lower cost, higher service reliability, high power quality and energy independence. Use renewable energy to supply the distributed energy resources system extra electricity. Like wind, photovoltaic, geothermal, biomass and hydroelectric power.

In the detached house, we set up storage batteries and fuel cell in the system. For the storage batteries, discharge cycle and charge cycle characteristics are excellent, batteries can be put through 500 or more cycles. Self-discharge is minimal, at fewer than $10 \%$ per month. Remaining capacity can easily be indicated using the discharge curve. Fuel cells combine hydrogen and oxygen without combustion to generate electricity. Water and heat are the only byproducts of this reaction. The fuel is converted to hydrogen by a series of chemical reactions in a processor. The resulting hydrogen is then combined with oxygen from the air in the fuel cell to generate electrical power in a single step. 
Case 6 in heat tracking mode has the maximum value which reaches $37 \%$. Also the time of storage batteries is fixed and does not store the residual energy, so the case 4 is greater than the case in the same mode, caused the energy loss more than $2 \%$. Because of using hydrogen fuel cell, comparing with conventional case, the $\mathrm{CO}_{2}$ emissions reduction rate increase obviously. Case 6 in heat tracking mode has the maximum value which reaches $55 \%$. Distributed energy resources system can enhance the operation efficiency more than $30 \%$. When we set up the PV system in the detached house, the energy reduction rate reaches more than $15 \%$ but also has waste. From case 3 to case 6, using hydrogen fuel cell, can cut down more than $30 \% \mathrm{CO}_{2}$ emissions.

In the future we will further improve the system in the detached house. Make full use of the energy consumption, enhance the operation efficiency. According to the price of gas and electricity; the subsidies of renewable energy application, we can discuss the economy energy usage and equipment cost. Fuel cell also generates heat in the detached house, but it will make energy loss in the system. We can talk about the heat accumulation in the detached house.

\section{References}

[1] Ren, H. and Gao, W.J. (2010) Economic and Environmental Evaluation of Micro CHP Systems with Different Operating Modes for Residential Buildings in Japan. Energy and Buildings, 42, 853-861.

[2] Enteria, N., et al. (2014) Case Analysis of Utilizing Alternative Energy Sources and Technologies for the Single Family Detached House. Solar Energy, 105, 243-263. http://dx.doi.org/10.1016/j.solener.2014.03.005

[3] Gustavsson, L., Joelsson, A., et al. (2007) Energy Conservation and Conversion of Electrical Heating Systems in Detached Houses. Energy and Buildings, 39, 717-726.

[4] De Paepe, M., D’Herdt, P. and Mertens, D. (2006) Micro-CHP Systems for Residential Applications. Energy Conversion and Management, 47, 3435-3446. http://dx.doi.org/10.1016/j.enconman.2005.12.024

[5] Joelsson, A. and Gustavsson, L. (2009) District Heating and Energy Efficiency in Detached Houses of Differing Size and Construction. Applied Energy, 86, 126-134. http://dx.doi.org/10.1016/j.apenergy.2008.03.012

[6] Rasoul Asaee, S., Ismet Ugursal, V. and Beausoleil-Morrison, I. (2015) Techno-Economic Evaluation of Internal Combustion Engine Based Cogeneration System Retrofits in Canadian Houses-A Preliminary Study. Applied Energy, 140, 171-183.

[7] Bruni, G., Cordiner, S. and Mulone, V. (2014) Domestic Distributed Power Generation: Effect of Sizing and Energy Management Strategy on the Environmental Efficiency of a Photovoltaic-Battery-Fuel Cell System. Energy, 77, 133143. http://dx.doi.org/10.1016/j.energy.2014.05.062

[8] Cao, S.L., Hasan, A. and Sirén, K. (2013) Analysis and Solution for Renewable Energy Load Matching for a Single-Family House. Energy and Buildings, 65, 398-411.

[9] Entchev, E., Yang, L., Ghorab, M. and Lee, E.J. (2014) Simulation of Hybrid Renewable Microgeneration Systems in Load Sharing Applications. Energy, 50, 252-261.

[10] Tibi, G., Ghaddar, N. and Ghali, K. (2012) Sustainable Design Guidelines for Detached Housing in the Lebanese Inland Region. International Journal of Sustainable Built Environment, 1, 177-193.

[11] Lund, H., Werner, S., Wiltshire, R., Svendsen, S., Thorsen, J.E., Hvelplund, F. and Mathiesen, B.V. (2014) 4th Generation District Heating (4GDH): Integrating Smart Thermal Grids into Future Sustainable Energy Systems. Energy, 68, 1-11. http://dx.doi.org/10.1016/j.energy.2014.02.089

[12] Entchev, E., Yang, L., Ghorab, M. and Lee, E.J. (2014) Performance Analysis of a Hybrid Renewable Microgeneration System in Load Sharing Applications. Applied Thermal Engineering, 71, 697-704. http://dx.doi.org/10.1016/j.applthermaleng.2013.10.057

[13] Mahkamov, K. (2011) 18-Thermal-Engine-Based Small and Micro Combined Heat and Power (CHP) Systems for Domestic Applications: Modelling Micro-CHP Deployment, Small and Micro Combined Heat and Power (CHP) Systems. A Volume in Woodhead Publishing Series in Energy, 459-509.

[14] Wiberg, A.H., Georges, L., Dokka, T.H., Haase, M., Time, B., Lien, A.G., Mellegård, S. and Maltha, M. (2014) A Net Zero Emission Concept Analysis of a Single-Family House. Energy and Buildings, 74, 101-110.

[15] Stefanović, A., Bojić, M. and Gordić, D. (2014) Achieving Net Zero Energy Cost House from Old Thermally Non-Insulated House Using Photovoltaic Panels. Energy and Buildings, 76, 57-63.

[16] Lepkova, N., Zubka, D. and Jensen, R.L. (2014) Chapter 10-Financial Investments for Zero Energy Houses: The Case of Near-Zero Energy Buildings. Global Sustainable Communities Handbook, 2014, 217-253. http://dx.doi.org/10.1016/j.apenergy.2010.02.002

[17] Amiri, S. and Moshfegh, B. (2010) Possibilities and Consequences of Deregulation of the European Electricity Market 
for Connection of Heat Sparse Areas to District Heating Systems. Applied Energy, 87, 2401-2410.

[18] Dorer, V. and Weber, A. (2009) Energy and $\mathrm{CO}_{2}$ Emissions Performance Assessment of Residential Micro-Cogeneration Systems with Dynamic Whole-Building Simulation Programs. Energy Conversion and Management, 50, 648-657.

[19] Gao, W.J. and Ren, H.B. (2011) An Optimization Model Based Decision Support System for Distributed Energy Systems Planning. International Journal of Innovative Computing, Information and Control, 7, 2651-2668. 